\title{
Uji Validitas Konstruk Instrumen Moral Disengagement
}

\author{
Dewi Mayangsari \\ UIN Syarif Hidayatullah Jakarta \\ mayang.dewimayangsari@gmail.com
}

\begin{abstract}
Moral disengagement can be a background for a person in conducting a behavior that is not humanly appropriate dan violating moral. The purpose of this research was to test the construct validity of the instrument of moral disengagement that developed by Hymel et al. (2005). The sample of this research was teenagers that actively used the internet, such as social media. Analysis method used to test this construct is Confirmatory Factor Analysis (CFA) using LISREL 8.80 software. The result of this study showed that all of the items which were tested, only one item is not unidimensional. Meaning of the 18 items which were proposed, 17 items measure only a factor.
\end{abstract}

Keywords: Construct Validity Test, Moral Disengagement, Cognitive Restructuring, Minimizing Agency, Distortion of Negative Consequences, Blaming/Dehumanizing the Victim

\begin{abstract}
Abstrak
Pelanggaran moral dapat menjadi landasan seseorang dalam melakukan perbuatan yang tidak manusiawi dan melanggar moral. Penelitian ini bertujuan untuk menguji validitas konstruk instrumen pelanggaran moral yang dikembangkan oleh Hymel et al. (2005). Sampel penelitian adalah remaja yang aktif menggunakan internet seperti media sosial. Metode analisis yang digunakan untuk menguji konstruk ini adalah confirmatory factor analysis (CFA) dengan menggunakan software LISREL 8.80. Hasil dari penelitian menunjukkan bahwa dari seluruh item yang diujikan, hanya satu item yang tidak bersifat unidimensional. Artinya keseluruhan 18 item yang diujikan, ada 17 item yang mengukur satu faktor saja.
\end{abstract}

Kata kunci: Uji Validitas Konstruk, Pelanggaran Moral, Struktur Ulang Kognitif, Minimalisir Agensi, Distorsi Konsekuensi Negatif, Menyalahkan/Melecehkan Korban 


\section{PENDAHULUAN}

Moral disengagement merupakan salah satu faktor internal yang memengaruhi remaja melakukan perilaku negatif, salah satunya bullying. Menurut Bandura (dalam Hymel, Henderson \& Bonanno, 2005) moral disengagement adalah suatu proses pemikiran sosial dimana rata-rata orang mampu melakukan perbuatan yang dapat menyakiti orang lain. Mekanisme yang terjadi dalam proses moral disengagement menurut Hymel, dkk. (2005) meliputi: cognitive restructuring (keyakinan untuk membingkai perilaku bahaya menjadi hal yang positif); minimizing agency (melimpahkan tanggung jawab ke orang yang otoritasnya lebih tinggi); distortion of negative consequnces (menjauhkan diri dari konsekuensi negatif); dan blaming/ dehumanizing the victim (menyalahkan dan merendahkan korban).

Banyak para ahli yang menjelaskan tentang definisi moral disengagement. Menurut Bandura (1999) moral disengagement adalah ketidakmampuan seseorang dalam mengontrol perilaku yang ia lakukan sehingga memungkinkannya untuk melakukan perilaku yang tidak manusiawi. Selanjutnya menurut Bandura (dalam Hymel et.al, 2005) memahami moral disengagement sebagai suatu proses sosio-kognitif di mana rata-rata orang mampu melakukan perbuatan yang mengerikan terhadap orang lain. Secara umum, moral disengagement dapat menjadi landasan seseorang dalam melakukan perbuatan yang tidak manusiawi dan melanggar moral.

Hymel, et.al., (2005) telah mengembangkan skala moral disengagement dimana ia mengklasifikasikan delapan mekanisme moral disengagementt menjadi empat klasifikasi, yaitu: cognitive restructuring, minimizing agency, distortion of negative consequences, blaming/dehumanizing the victim. Instrument ini terdiri dari 18 item, dimana terdapat 14 item favorable dan 4 item unfavorable.

Skala moral disengagement ini menggunakan model skala likert dengan empat kategori jawaban untuk menghindari terjadinya pemusatan (central tendency) atau menghindari jumlah respon yang bersifat netral, yaitu dengan pilihan jawaban: "Sangat Setuju" (SS), "Setuju” (S), "Tidak Setuju” (TS), "Sangat Tidak Setuju" (STS). Penyekoran dilakukan dengan memberikan penilaian tertinggi pada pernyataan "Sangat Setuju" (SS) dan terendah pada pilihan "Sangat Tidak Setuju” (STS) untuk pernyataan favorable. Untuk penyekoran item unfavorable, penilaian tertinggi pada pernyataan "Sangat Tidak Setuju" (STS) dan terendah pada pilihan "Sangat Setuju" (SS). Skor - skor tersebut kemudian dihitung, dengan proporsi item yang yang bersifat favorable dengan ketentuan sebagai berikut: $\mathrm{SS}=4, \mathrm{~S}=3, \mathrm{TS}=2, \mathrm{STS}=1$. Untuk item yang bersifat unfavorable dihitung dengan ketentuan sebagai berikut: $\mathrm{SS}=1, \mathrm{~S}=2, \mathrm{TS}=3, \mathrm{STS}=4$.

Untuk mengetahui moral disengagement diperlukan alat ukur yang terstandar. Namun belum banyak alat ukur tentang moral disengagement yang berkembang baik di Indonesia maupun di luar negeri. Oleh Karena itu, penting untuk mengembangkan sebuah alat ukur yang berkaitan dengan moral disengagement. 


\section{METODE}

Untuk menguji validitas konstruk instrumen moral disengagement, peneliti menggunakan pendekatan analisis faktor yaitu confirmatory factor analysis (CFA). Pengujian analisis CFA seperti ini dilakukan dengan bantuan software LISREL 8.80 (Joreskog \& Sorbom, 1999).

Adapun logika dasar dari CFA adalah sebagai berikut (Umar, 2012):

1. Menguji hipotesis, apakah semua item mengukur satu konstruk yang didefinisikan. Ide dari tahap pertama ini ialah apabila tidak ada selisih (residu) antara data $(\mathrm{S})$ dengan teori $\left(\sum\right)$, maka suatu model dapat dikatakan fit dengan data. Dalam hal ini $\sum$ adalah matriks korelasi antar item menurut $\mathrm{H}_{0}$, sedangkan $\mathrm{S}$ adalah matriks korelasi antar item yang diperoleh dari observasi. Apabila terdapat perbedaan yang signifikan antara teori dengan data, maka suatu model dikatakan tidak fit dengan data. Hipotesis nihil yang berbunyi "tidak ada perbedaan antara matriks $\sum$ dengan matriks $S$ ” kemudian diuji dengan chi-square. Jika chi-square tidak signifikan atau p>0,05, maka hipotesis nihil tersebut "tidak ditolak". Artinya teori unidimensionalitas tersebut dapat diterima, dimana itemnya hanya mengukur satu faktor saja.

2. Menguji hipotesis, apakah setiap item menghasilkan informasi secara signifikan tentang konstruk yang diukur. Pada tahap ini, penulis menentukan item mana yang akan valid dan item mana yang tidak valid. Adapun kriteria item yang baik pada CFA adalah sebagai berikut (Umar, 2012):

a. Melihat signifikan tidaknya suatu item dalam memberikan informasi tentang suatu konstruk. Perbandingannya adalah jika t > 1,96 maka item tersebut signifikan dan sebaliknya.

b. Melihat koefisien muatan faktor dari item. Jika item tersebut sudah di-scoring secara favorable (pada skala likert 1-4), maka nilai koefisien muatan faktor pada item harus bermuatan positif, dan sebaliknya. Apabila item tersebut favorable, namun koefisien muatan faktor item bernilai negatif maka mengindikasikan bahwa item tersebut tidak valid.

c. Terakhir, apabila kesalahan pengukuran item terlalu banyak berkorelasi, maka item tersebut tidak baik, dan disarankan untuk dieliminasi. Sebab, item yang demikian selain mengukur apa hendak diukur, ia juga mengukur hal lain.

Adapun data dalam penelitian ini diperoleh dari pengisian angket dari remaja yang aktif menggunakan internet seperti sosial media Data tersebut dikumpulkan dalam rangka penyusunan skripsi (Mayangsari, 2015). 


\section{HASIL}

Dalam penelitian ini, dilakukan uji validitas dengan model analisis per dimensi. Alat ukur yang diuji memiliki empat dimensi sehingga terdapat empat hasil analisis. Adapun hasil uji validitas tersebut diuraikan berikut ini.

\section{Cognitive Restructuring}

Peneliti menguji apakah lima item yang ada bersifat unidimensional, artinya benar hanya mengukur cognitive restructuring. Dari hasil analisis CFA yang dilakukan dengan model satu faktor menghasilkan chi - square $=26,94, \mathrm{df}=5, p$-value $=0,00006$, dan RMSEA = 0,151 yang berarti tidak fit . Namun, setelah melakukan modifikasi terhadap model, dimana kesalahan pengukuran pada beberapa item dibebaskan berkorelasi satu sama lainnya, maka diperoleh model fit dengan nilai chi-square $=6,13$, df $=3, P$-value $=$ 0,10552, dan RMSEA = 0,074 yang artinya model dengan satu faktor (unidimensional) dapat diterima bahwa seluruh item mengukur satu faktor saja yaitu cognitive restructuring seperti terlihat pada gambar di bawah ini:

\section{Gambar 1}

Path diagram faktor cognitive restructuring

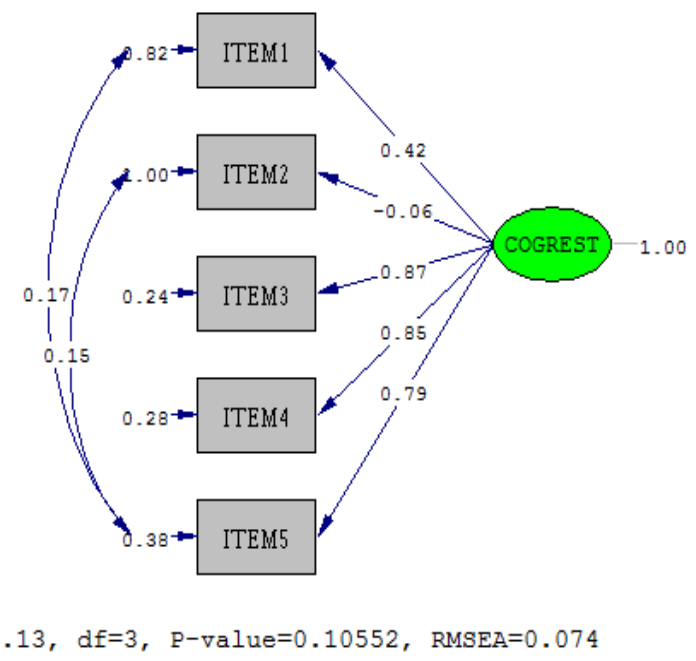

Terlihat dari gambar di atas bahwa model fit dengan nilai chi-square menghasilkan $\mathrm{p}>0,05$ (tidak signifikan). Dengan demikian model dengan satu faktor dapat diterima, yang berarti bahwa seluruh item terbukti mengukur satu hal saja, yaitu cognitive restructuring.

Selanjutnya, peneliti melihat apakah item tersebut secara signifikan mengukur faktor yang hendak diukur, sekaligus menentukan apakah item tersebut perlu dieliminasi atau tidak. Maka dilakukan pengujian 
hipotesis nihil tentang koefisien muatan faktor item. Pengujiannya dilakukan dengan melihat nilai t bagi setiap koefisien muatan faktor, seperti pada tabel 1 berikut.

\section{Tabel 1}

\section{Muatan Faktor Item Cognitive Restructuring}

\begin{tabular}{ccccc}
\hline No. item & Koefisien & Standar error & Nilai t & Signifikan \\
\hline 1 & 0.42 & 0.07 & 5.67 & $\sqrt{ }$ \\
2 & -0.06 & 0.08 & -0.78 & $X$ \\
3 & 0.87 & 0.06 & 14.27 & $\sqrt{ }$ \\
4 & 0.85 & 0.06 & 13.75 & $\sqrt{ }$ \\
5 & 0.79 & 0.06 & 12.37 & $\sqrt{ }$ \\
\hline
\end{tabular}

Keterangan $: \sqrt{ }=$ Signifikan $(t>1.96) ; X=$ Tidak Signifikan

Dari tabel di atas dapat dilihat hanya nilai t bagi koefisien muatan faktor dari item nomor 2 tidak signifikan, sedangkan koefisien muatan faktor item lainya signifikan. Dapat dilihat pula pada kolom koefisien terdapat item yang muatan faktornya negatif, yaitu item nomor 2. Dengan demikian, item nomor 2 di-drop.

\section{Minimizing Agency}

Peneliti menguji apakah tiga item yang ada bersifat unidimensional, artinya benar hanya mengukur minimizing agency. Dari hasil analisis CFA yang dilakukan dengan model satu faktor, hasilnya fit, dengan chi-quare $=55,67, \mathrm{df}=0, P$-value $=1,00000$, dan RMSEA $=0,000$ yang artinya model dengan satu faktor (unidimensional) dapat diterima bahwa seluruh item mengukur satu faktor saja yaitu minimazing agency, seperti terlihat pada gambar berikut ini:

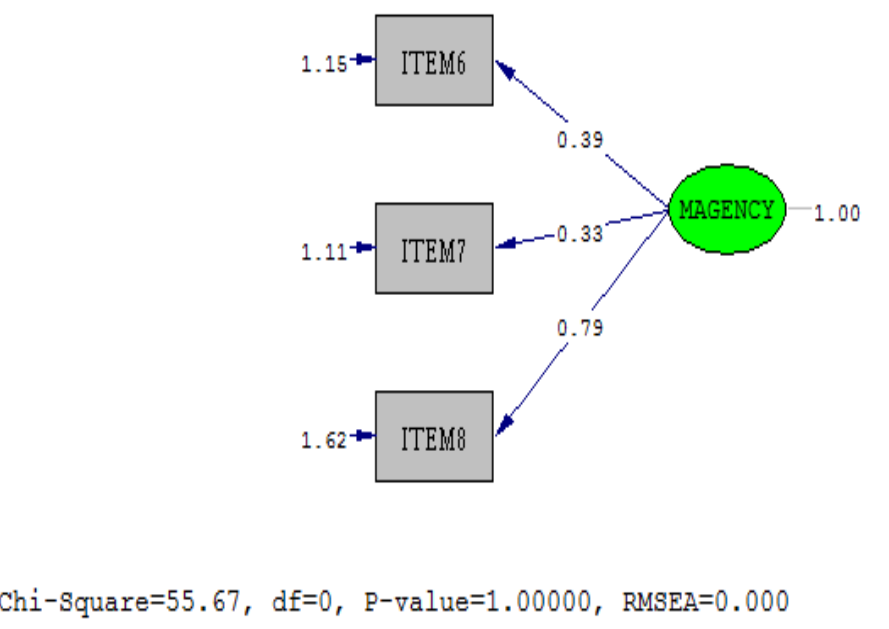

Gambar 2

Path Diagram Faktor Minimizing Agency 
Terlihat dari gambar di atas bahwa model fit dengan nilai chi-square menghasilkan $\mathrm{p}>0,05$ (tidak signifikan). Dengan demikian model dengan satu faktor dapat diterima, yang berarti bahwa seluruh item terbukti mengukur satu hal saja, yaitu minimizing agency.

Selanjutnya, peneliti melihat apakah item tersebut secara signifikan mengukur faktor yang hendak diukur, sekaligus menentukan apakah item tersebut perlu dieliminasi atau tidak. Maka dilakukan pengujian hipotesis nihil tentang koefisien muatan faktor item. Pengujiannya dilakukan dengan melihat nilai t bagi setiap koefisien muatan faktor, seperti pada tabel 2 berikut:

Tabel 2

Muatan Faktor Item Minimizing Agency

\begin{tabular}{ccccc}
\hline No. item & Koefisien & Standar error & Nilai t & Signifikan \\
\hline 6 & 0.39 & 0.17 & 2.23 & $\sqrt{ }$ \\
7 & 0.33 & 0.15 & 2.16 & $\sqrt{ }$ \\
8 & 0.79 & 0.33 & 2.39 & $\sqrt{ }$ \\
\hline
\end{tabular}

Keterangan $: \sqrt{ }=$ Signifikan $(\mathrm{t}>1.96) ; \mathrm{X}=$ Tidak Signifikan

Berdasarkan tabel di atas, dapat dilihat seluruh item memiliki t $>1,96$ yang artinya koefisien muatan faktor item-item tersebut signifikan. Pada kolom koefisien tidak terdapat item yang muatan faktornya negatif. Berarti, secara keseluruhan tidak ada item yang di-drop.

\section{Distortion of Negative Consequences}

Peneliti menguji apakah empat item yang ada bersifat unidimensional, artinya benar hanya mengukur distortion of negative consequences. Dari hasil analisis CFA yang dilakukan dengan model satu faktor menghasilkan Chi-square $=31,02, \mathrm{df}=2, P$-value $=0,00000$, dan RMSEA $=0,274$ yang berarti tidak fit . Namun, setelah melakukan modifikasi terhadap model, dimana kesalahan pengukuran pada beberapa item dibebaskan berkorelasi satu sama lainnya, maka diperoleh model fit dengan nilai Chi-square $=0.05$, $\mathrm{df}=$ 1, $P$-value $=0.82496$, dan RMSEA $=0.000$ yang artinya model dengan satu faktor (unidimensional) dapat diterima bahwa seluruh item mengukur satu faktor saja yaitu distortion of negative consequences, seperti terlihat pada gambar berikut ini: 


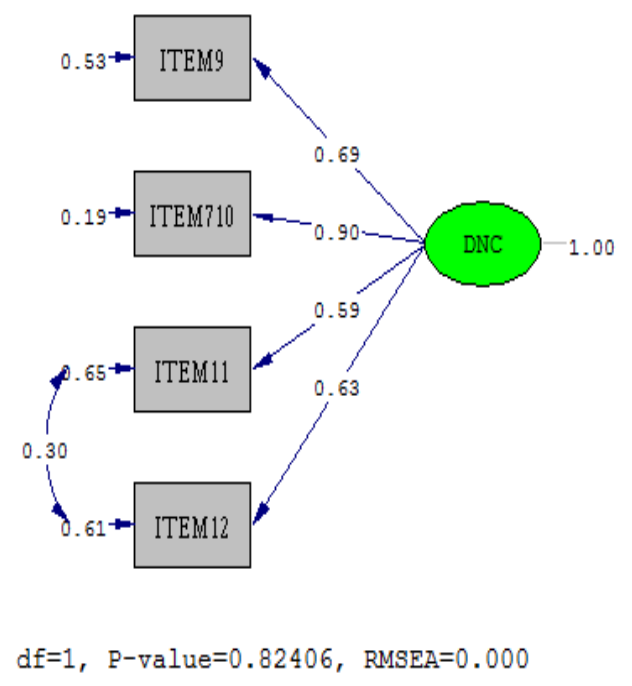

Gambar 3

Path Diagram Faktor Distortion of Negative Consequences

Terlihat dari gambar di atas bahwa model fit dengan nilai chi-square menghasilkan $\mathrm{p}>0,05$ (tidak signifikan). Dengan demikian model dengan satu faktor dapat diterima, yang berarti bahwa seluruh item terbukti mengukur satu hal saja, yaitu distortion of negative consequences.

Selanjutnya, peneliti melihat apakah item tersebut secara signifikan mengukur faktor yang hendak diukur, sekaligus menentukan apakah item tersebut perlu dieliminasi atau tidak. Maka dilakukan pengujian hipotesis nihil tentang koefisien muatan faktor item. Pengujiannya dilakukan dengan melihat nilai t bagi setiap koefisien muatan faktor, seperti pada tabel 3 berikut.

Tabel 3

Muatan Faktor Item Distortion of Negative Consequences

\begin{tabular}{ccccc}
\hline No. item & Koefisien & Standar error & Nilai t & Signifikan \\
\hline 9 & 0.69 & 0.07 & 9.57 & $\sqrt{ }$ \\
10 & 0.90 & 0.07 & 12.54 & $\sqrt{ }$
\end{tabular}




\begin{tabular}{lllll}
11 & 0.59 & 0.07 & 8.03 & $\sqrt{ }$ \\
12 & 0.63 & 0.07 & 8.60 & $\sqrt{ }$ \\
\hline
\end{tabular}

Keterangan $: \sqrt{ }=$ Signifikan $(\mathrm{t}>1.96) ; \mathrm{X}=$ Tidak Signifikan

Berdasarkan tabel di atas, dapat dilihat seluruh item memiliki $t>1,96$ yang artinya koefisien muatan faktor item-item tersebut signifikan. Pada kolom koefisien tidak terdapat item yang muatan faktornya negatif. Berarti, secara keseluruhan tidak ada item yang di-drop.

\section{Blaming/Dehumanizing the Victim}

Peneliti menguji apakah enam item yang ada bersifat unidimensional, artinya benar hanya mengukur blaming/ dehumanizing the victim. Dari hasil analisis CFA yang dilakukan dengan model satu faktor menghasilkan chi-square $=51,00, \mathrm{df}=9, P$-value $=0,00000$, dan RMSEA $=0,155$ yang berarti tidak fit . Namun, setelah melakukan modifikasi terhadap model, dimana kesalahan pengukuran pada beberapa item dibebaskan berkorelasi satu sama lainnya, maka diperoleh model fit dengan nilai chi-square $=9,88$, df $=7$, $P$-value $=0,19537$, dan RMSEA $=0,046$ yang artinya model dengan satu faktor (unidimensional) dapat diterima bahwa seluruh item mengukur satu faktor saja yaitu blaming/dehumanizing the victim seperti terlihat pada gambar berikut ini:

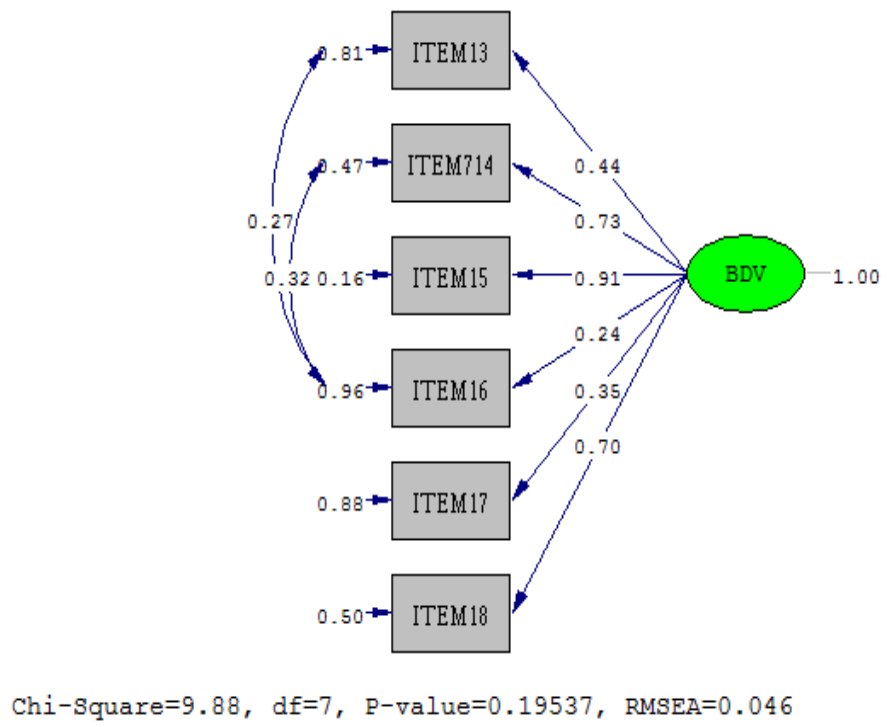

Gambar 4

Path Diagram Faktor Blaming/Dehumanizing the Victim

Terlihat dari gambar di atas bahwa model fit dengan nilai Chi-square menghasilkan $\mathrm{p}>0,05$ (tidak signifikan). Dengan demikian model dengan satu faktor dapat diterima, yang berarti bahwa seluruh item terbukti mengukur satu hal saja, yaitu blaming/dehumanizing the victim. 
Selanjutnya, peneliti melihat apakah item-item tersebut secara signifikan mengukur faktor yang hendak diukur, sekaligus menentukan apakah item tersebut perlu dieliminasi atau tidak. Maka dilakukan pengujian hipotesis nihil tentang koefisien muatan faktor item. Pengujiannya dilakukan dengan melihat nilai $\mathrm{t}$ bagi setiap koefisien muatan faktor, seperti terlihat pada tabel 4 berikut.

\section{Tabel 4}

Muatan Faktor Item Blaming/Dehumanizing the Victim

\begin{tabular}{ccccc}
\hline No. item & Koefisien & Standar error & Nilai t & Signifikan \\
\hline 13 & 0.44 & 0.07 & 6.05 & $\sqrt{ }$ \\
14 & 0.73 & 0.07 & 10.96 & $\sqrt{ }$ \\
15 & 0.91 & 0.06 & 14.76 & $\sqrt{ }$ \\
16 & 0.24 & 0.08 & 3.13 & $\sqrt{ }$ \\
17 & 0.35 & 0.07 & 4.68 & $\sqrt{ }$ \\
18 & 0.70 & 0.07 & 10.55 & $\sqrt{ }$ \\
\hline
\end{tabular}

Keterangan $: \sqrt{ }=$ Signifikan $(\mathrm{t}>1.96) ; \mathrm{X}=$ Tidak Signifikan

Berdasarkan tabel di atas, dapat dilihat seluruh item memiliki $\mathrm{t}>1$,96 yang artinya koefisien muatan faktor item-item tersebut signifikan. Pada kolom koefisien tidak terdapat item yang muatan faktornya negatif. Secara keseluruhan tidak ada item yang dieliminasi.

\section{DISKUSI}

Hasil uji validitas konstruk terhadap instrumen moral disengagement dengan menggunakan pendekatan confirmatory factor analysis mengungkapkan bahwa setelah dilakukan pembebasan korelasi antar item sehingga diperoleh hasil 4 item dari 5 item keseluruhan yang ada bersifat unidimensional atau dengan kata lain hanya mengukur satu faktor saja, yakni cognitive restructuring, 3 item keseluruhan mengukur minimizing agency, 4 item keseluruhan mengukur distortion of negative consequences, dan 6 item keseluruhan mengukur blaming/dehumanizing the victim.

Dapat disimpulkan bahwa model satu faktor yang dibuat berdasarkan teori moral disengagement berdasarkan empat mekanismenya seperti yang dikemukakan oleh Hymel, et.el., (2005) ini dapat diterima. Hal ini dikarenakan 17 item dalam instrumen ini memenuhi kriteria-kriteria sebagai item yang baik, yaitu (1) memiliki muatan faktor positif, (2) valid (signifikan $t>1.96$ ), dan (3) memiliki korelasi antarkesalahan pengukuran item yang dapat ditoleransi dengan kata lain item tersebut bersifat unidimensional. 


\section{DAFTAR PUSTAKA}

Bandura, A., Barbaraneli, C., Caprara, G., \& Pastoreli, C. (1996). Mechanisms of moral disengagement in the exercise of moral agency. Personality and Social Psychology Review, 71, 364-374

Bandura, A. (1999). Moral disengagement in the perpetration of inhumanities. Personality and Social Psychology Review, 3(3), 193-209. Lawrence Erlbaum Associates: Inc. Stanford University.

Detert, J.R., Trevino, L.K., \& Sweitzer, V.L. (2008). Moral disengagement in ethical decision making: A study of antecedences and outcomes. Journal of Applied Psychology, 93(2), 374-391

Hymel, S., Henderson, N.R., \& Bonanno, R.A. (2005). Moral disengagement: A framework for understanding bullying among adolescents. Journal of Social Science. Special Issue no. 8, 1-11

South, C. R., \& Wood, J. (2006). Bullying in prisons: The importance of perceived social status, prisonization, and moral disengagement. Agressive Behavior, 32, 490-501.

Umar, J. (2012). Analisis faktor. Modul perkuliahan. Fakultas Psikologi. UIN Jakarta. Tidak dipublikasikan. 